\title{
PENGEMBANGAN LABORATORIUM VIRTUAL BERBASIS MULTIMEDIA INTERAKTIF PADA PRAKTIKUM TITRASI ASAM BASA
}

\author{
Reny, Sugiarti ${ }^{1}$, Pince Salempa ${ }^{2}$ \\ ${ }^{1,2}$ Dosen Program Pascasarjana Universitas Negeri Makassar \\ Email: rhenydefrely@gmail.com
}

\begin{abstract}
ABSTRAK
Penelitian ini bertujuan untuk mengembangkan laboratorium virtual dan untuk mengetahui kevalidan, kepraktisan dan keefektifan laboratorium virtual berbasis multimedia interaktif sebagai media pembelajaran pada praktikum titrasi asam basa. Diharapkan produk yang dikembangkan dapat meningkatkan hasil belajar peserta didik. Penelitian ini merupakan penelitian pengembangan dengan menggunakan model pengembangan berbasis produk Hannafin dan Peck yang terdiri dari tiga fase yaitu fase analisis kebutuhan, fase desain, dan fase pengembangan/implementasi. Subjek uji coba produk pengembangan ini adalah siswa kelas XI MIA3 SMA Negeri 6 Takalar dengan jumlah siswa 28 orang. Dalam penelitian ini, teknik pengumpulan data menggunakan kuesioner dengan skala Likert. Teknik analisis data yang digunakan yaitu analisis statistik deskriptif. Hasil penelitian menunjukkan bahwa untuk semua item dan aspek yang diukur, penilaian kevalidan media memperoleh kriteria valid, penilaian kepraktisan media berada pada kategori praktis dan keefektifan dengan $\mathrm{N}$-gain $=$ 0.785 dengan kategori tinggi. Dari hasil tersebut menujukkan media laboratorium virtual berbasis multimedia interaktif yang dikembangkan memiliki kategori valid, praktis dan efektif, sehingga dapat disimpulkan media laboratorium virtual berbasis multimedia interaktif yang dikembangkan layak dijadikan sebagai media pembelajaran.
\end{abstract}

Kata kunci : Laboratorium Virtual, Multimedia Interaktif, Titrasi Asam-basa.

\begin{abstract}
This research aims to develop virtual laboratory in order to find its validity, practicality, and effectiveness of virtual laboratory interactive multimedia based in acids bases titration experiment. It is expected that the product developed can improve learning outcomes. This developing research uses a developing model based on Hannafin and Peck product. It contains three phases which are need analysis phase, design phase, and developing or implementing phase. The subjects of this developing product are 28 students of SMA Negeri 6 Takalar class XI MIA3. In collecting the data, the researcher applies questionnaire using Likert Scale. Data were analyzed by using descriptive statistics analysis. The findings of this research show valid of all aspects and items that have been measured for its validity and pratical for its media practicality and effective with the pretest-posttest show gain $=0.785$ high category. It is concluded that the developing of virtual laboratory interactive multimedia based in acids bases titration experiment proves as valid, practical, and effective which can be properly applied as the learning media.
\end{abstract}

Keywords: Virtual Laboratory, Interactive Multimedia, Acids Bases Tiration 


\section{PENDAHULUAN}

Ilmu kimia dalam bahasa Inggris diterjemahkan sebagai chemistry, dan jika dipenggal menjadi Chem-is-Try, yang dapat diartikan kimia tidak bisa dikatakan kimia jika tanpa eksperimen (try). Ilmu kimia diperoleh dan dikembangkan melalui eksperimen untuk mencari jawaban atas berbagai peristiwa yang terjadi di alam, khususnya yang berkaitan dengan komposisi, struktur, sifat, energetika, serta reaksi-reaksi yang terjadi. Telah disinggung di atas bahwa ilmu kimia diperoleh dan dikembangkan melalui eksperimen, sehingga akan lebih efektif jika dalam pembelajaran kimia juga melibatkan eksperimen yang dilakukan oleh peserta didik. Peserta didik akan memiliki pengalaman langsung dan dapat lebih mudah mengerti dan memahami ilmu yang dipelajarinya. Tetapi, terkadang peserta didik menghadapi kendala untuk melakukan kegiatan praktikum. Masalah yang terjadi sehingga peserta didik jarang melakukan kegiatan praktikum yaitu keterbatasan sarana dan prasarana praktikum.

Suatu kegiatan praktikum bisa dilaksanakan walaupun tanpa adanya alatalat praktikum seperti biasanya. Hal ini bisa dilaksanakan dengan cara melakukan kegiatan laboratorium (praktikum) secara virtual, yaitu pemanfaatan suatu laboratorium untuk mewujudkan konsep yang abstrak ke dalam visualisasi dengan bantuan teknologi komputer.

Penelitian yang dilakukan oleh (Tüysüz, 2010) pada Pengaruh Laboratorium Virtual Terhadap Prestasi Peserta didik dan Sikap dalam Kimia menunjukkan bahwa laboratorium virtual memberikan pengaruh positif terhadap sikap dan hasil belajar peserta didik. Penelitian yang diakukan (Dianty. 2014) pada perbandingan pengaruh antara pembelajaran menggunakan laboratorium konvensional dan virtual terhadap hasil belajar menunjukkan bahwa tidak ada perbedaan pengaruh antara pembelajaran menggunakan laboratorium virtual dan laboratorium konvensional dalam pembelajaran kimia terhadap hasil belajar peserta didik kelas XII IPA SMA Negeri 3 Makale pada materi pokok sel elektrokimia. Adapun saran dari salah satu penelitian tersebut yaitu perlu dilakukan peneltian lebih lanjut mengenai penggunaan laboratorium virtual sebagai media belajar mandiri peserta didik.

Berawal dari saran salah satu penelitian diatas, maka peneliti akan mengembangkan media laboratorium virtual berbasis multimedia interaktif pada praktikum titrasi asam basa. Laboratorium virtual didefinisikan sebagai lingkungan yang interaktif untuk menciptakan dan melakukan eksperimen secara simulasi. Laboratorium virtual merupakan suatu media pembelajaran yang menyajikan proses pelaksanaan praktikum dalam suatu simulasi komputer. Multimedia interaktif merupakan media penyampaian yang memiliki unsur audiovisual dengan pemanfaatan komputer untuk membuat dan menggabungkan teks, grafik, audio, video dan animasi, dimana hasil penggabungan unsur-unsur tersebut akan menampilkan informasi yang lebih interaktif.

Adapun hasil sebaran angket di SMA Negeri 6 Takalar, ternyata peserta didik sangat tertarik untuk melakukan praktikum dengan menggunakan laboratorium virtual dengan alasan peserta didik dengan mudah melakukan praktikum dan peserta didik dapat mengetahui sejauh mana teknologi mendukung proses belajar pembelajaran. Sebagian besar peserta didik telah memiliki komputer atau laptop dan sering mengakses internet untuk memperoleh materi untuk mengerjakan tugas dan sebagai sarana interaksi sosial. Oleh karena itu, peneliti berharap dengan menggunakan laboratorium virtual peserta didik seolaholah telah melakukan percobaan seperti yang ditampilkan dalam komputer sehingga dapat membuktikan konsep yang ada seperti pada materi titrasi asam basa. 
Laboratorium virtual yang dirancang dapat memuat cakupan standar kompetensi dan kompetensi dasar, indikator, ringkasan materi, dan praktikum yang bersifat interaktif. Selanjutnya pada proses pembelajaran, dilakukan pengamatan aktivitas peserta didik dan menganalisis persepsinya terhadap pembelajaran yang telah dilakukan. Peneliti mengambil judul "Pengembangan Laboratorium Virtual berbasis Multimedia Interaktif Pada Praktikum Titrasi Asam Basa".

\section{METODE PENELITIAN}

Penelitian ini adalah penelitian pengembangan (Research and Development) yang bertujuan untuk mengembangkan laboratorium virtual berbasis multimedia interaktif pada praktikum titrasi asam basa. Penelitian ini dilaksanakan di SMA Negeri 6 Takalar dan subyek ujicoba penelitian adalah peserta didik kelas XI MIA 3 dengan jumlah peserta didik 28 orang.

Pengembangan media pembelajaran menggunakan model pengembangan berbasis produk Hannafin dan Peck yang terdiri dari tiga fase yaitu fase analisis kebutuhan, fase desain, dan fase pengembangan/implementasi

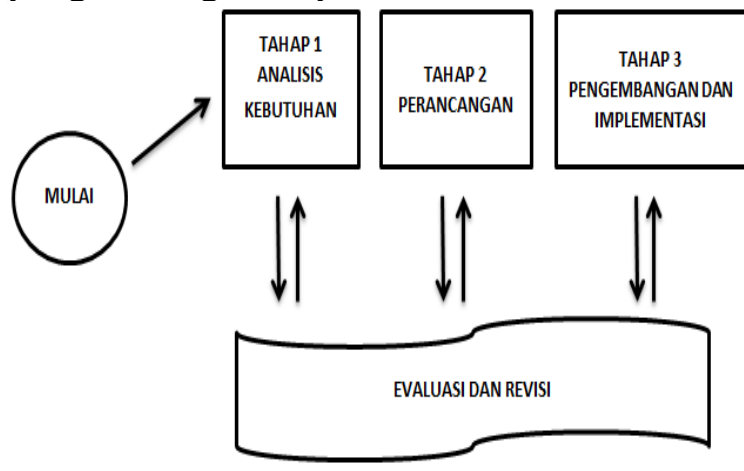

Gambar 1. Bagan Langkah Model Pengembangan Hannafin dan Peck

Instrumen penelitian yang digunakan untuk mengumpulkan data adalah kuesioner/angket. Instrumen kuesioner pada penelitian pengembangan ini berupa lembar validasi oleh ahli materi, lembar validasi oleh ahli media, lembar respon guru dan peserta didik, lembar pengamatan pengelolaan pembelajaran, lembar aktifitas peserta didik. Sedangkan data tes hasil belajar diperoleh dari pemberian pretestposttest.

Teknik pengumpulan data menggunakan kuesioner dengan skala Likert. Teknik analisis data yang digunakan yaitu analisis statistik deskriptif.

\section{HASIL DAN PEMBAHASAN}

1. Proses Pengembangan Laboratorium Virtual Berbasis Multimedia Interaktif

a. Deskripsi Hasil Tahap Penilaian Kebutuhan (Need Assessment)

Analisis kebutuhan dilakukan untuk mengidentifikasi kebutuhan-kebutuhan dalam mengembangkan suatu media pembelajaran. Studi pendahuluan ini meliputi observasi, wawancara dengan guru dan studi pustaka.

Tabel 1 Analisis Kebutuhan dari Hasil Wawancara dan Observasi

\begin{tabular}{|c|c|c|}
\hline No & $\begin{array}{c}\text { Aspek } \\
\text { kebutuhan }\end{array}$ & Deskripsi \\
\hline 1 & $\begin{array}{c}\text { Wawancara } \\
\text { guru }\end{array}$ & $\begin{array}{l}\text { Dalam kegiatan pembelajaran } \\
\text { sudah baik, guru biasa } \\
\text { menerapkan variasi model } \\
\text { pembelajaran yang telah dia } \\
\text { dapatkan. Media pembelajaran } \\
\text { juga sering diupayakan oleh } \\
\text { guru dalam mengajar. Metode } \\
\text { dan media yang digunakan } \\
\text { selama ini cukup efektif dan } \\
\text { efisien dalam pembelajaran. } \\
\text { Akan tetapi, guru merasa masih } \\
\text { menginginkan sebuah inovasi } \\
\text { yang dapat dikembangkan lagi } \\
\text { dalam pembelajaran sehingga } \\
\text { peserta didik kaya akan } \\
\text { pengalaman belajar dan } \\
\text { pengalaman praktikum, karena } \\
\text { masih ada beberapa peserta } \\
\text { didik yang kurang memahami } \\
\text { dan memperhatikan materi yang } \\
\text { disampaikan. Oleh karena itu, } \\
\text { guru pada sekolah ini sangat } \\
\text { mengharapkan media yang } \\
\text { dapat dijadikan sebagai salah } \\
\text { satu alternatif dalam melakukan } \\
\text { praktikum., sehingga peserta } \\
\text { didik belajar mandiri dan } \\
\text { meningkatkan hasil belajar } \\
\text { peserta didik. }\end{array}$ \\
\hline 2 & Angket & Peserta didik jarang melakukan \\
\hline
\end{tabular}




\begin{tabular}{|c|c|l|}
\hline & $\begin{array}{c}\text { Peserta } \\
\text { Didik }\end{array}$ & $\begin{array}{l}\text { praktikum dan mereka tertarik } \\
\text { untuk melakukan praktikum } \\
\text { menggunakan laboratorium } \\
\text { virtual. Peserta didik ingin } \\
\text { melihat sejauh mana teknologi } \\
\text { mendukung proses } \\
\text { pembelajaran. }\end{array}$ \\
\hline 3 & Fasilitas & $\begin{array}{l}\text { Cukup memadai sebagai syarat } \\
\text { terciptanya pembelajaran dan } \\
\text { laboratorium virtual. Papan tulis } \\
\text { tersedia, dan ada LCD proyektor } \\
\text { yang dapat diambil di ruangan } \\
\text { guru. Laboratorium kimia dan } \\
\text { perpustakaan serta laboratorium } \\
\text { komputer tersedia. }\end{array}$ \\
\hline 4 & $\begin{array}{l}\text { Analisis } \\
\text { konsep }\end{array}$ & Menggunakan kurikum 2013 \\
\hline
\end{tabular}

b. Fase Perancangan (Design)

Tahap awal dari fase ini dilakukan perancangan media produk I yaitu media laboratorium virtual berbasis multimedia interaktif yang dikembangkan secara keseluruhan membahas tentang materi titrasi asam basa.

Setelah produk laboratorium virtual berbasis multimedia interaktif dibuat, dilakukan validasi dan uji coba perorangan (one to one trying out) sebagai proses evaluasi yang merupakan rangkaian dari model Hannafin dan Peck. Hasil evaluasi yang diperoleh masih berupa komentar dan masukan terhadap media laboratorium virtual berbasis multimedia interaktif yang kemudian saran tersebut digunakan untuk merevisi media yang tengah dikembangkan ini.

Tabel 2 Perbandingan Produk I dan Produk II

\begin{tabular}{|l|l|l|}
\hline \multicolumn{1}{|c|}{$\begin{array}{c}\text { Bahan } \\
\text { Pembanding }\end{array}$} & \multicolumn{1}{|c|}{ Produk I Produk II } \\
\hline Materi Pokok & Titrasi Asam Basa & \multicolumn{1}{|c|}{ Titrasi Asam Basa } \\
\hline $\begin{array}{l}\text { Tampilan media } \\
\text { laboratorium } \\
\text { virtual berbasis } \\
\text { multimedia } \\
\text { interaktif }\end{array}$ & $\begin{array}{l}\text { Sederhana,tampilan } \\
\text { media tidak begitu } \\
\text { menarik,gambar polos, } \\
\text { ukuran huruf perlu } \\
\text { diperbesar, perlu ada } \\
\text { tambahan navigasi dan } \\
\text { background diubah }\end{array}$ & $\begin{array}{l}\text { Menarik, karena full color } \\
\text { dan background sudah } \\
\text { cocok. Perlu tambahan } \\
\text { home pada simulasi } \\
\text { praktikum. }\end{array}$ \\
\hline $\begin{array}{l}\text { Tampilan } \\
\text { simulasi } \\
\text { praktikum }\end{array}$ & $\begin{array}{l}\text { Sederhana, ukuran } \\
\text { huruf diperbesar dan } \\
\text { perlu tambahan tujuan } \\
\text { pembelajaran pada } \\
\text { simulasi praktikum }\end{array}$ & $\begin{array}{l}\text { Menarik tapi masih perlu } \\
\text { diubah pada proses titrasi, } \\
\text { dimana corong dilepas } \\
\text { ketika melakukan titrasi. } \\
\text { Perlu juga tambahan alat } \\
\text { pipet volume sehingga } \\
\text { ketika mengisi labu } \\
\text { erlenmeyer lakukan di } \\
\text { samping buret dan } \\
\text { gunakan pipet volum } \\
\text { untuk mengambil larutan }\end{array}$ \\
\hline
\end{tabular}

c. Fase Pengembangan dan Implementasi

Tahap ini dilakukan sebelum melanjutkan penelitian ke tahap selanjutnya yaitu tahap uji coba terbatas. Penilaian dilakukan oleh ahli media dan ahli materi dengan tujuan untuk mengetahui kelayakan desain media dan produk media pembelajaran berdasarkan pemikiran rasional, belum berdasarkan fakta di lapangan.

\section{Kualitas Hasil Pengembangan (Produk)}

a. Analisis Data Kevalidan

Tabel 3 Data Tabulasi Angket oleh Ahli Media

\begin{tabular}{|c|c|c|}
\hline \multicolumn{3}{|l|}{ Aspek Kualitas Tampilan } \\
\hline Kriteria & Validator & Keterangan \\
\hline $\begin{array}{l}\text { a. Petunjul instruksi penggunan pro gram ielas dan } \\
\text { mudah dimengerti }\end{array}$ & 5 & Sangat Valid \\
\hline b. Kombingsi latar depan dan latar belakang sesusi & 4 & Valid \\
\hline c. Teks atau talisan mudah terbaca & 3 & Cukup Valid \\
\hline d. Simulasi tampilan menarik & 4 & Valid \\
\hline e. Gambar mendukung peyamp gian materi & 5 & Sangat Valid \\
\hline $\begin{array}{l}\text { f. Tata letak gambar, grafik, dan teks memudahkan } \\
\text { penyimak untuk memahami materi }\end{array}$ & 4 & Valid \\
\hline g. Iringan musik mendukung suasang belajar & 4 & Sangat Valid \\
\hline Rata-Rata & 4,14 & Valid \\
\hline \multicolumn{3}{|l|}{ Aspek Daya Tarik } \\
\hline Kriteria & Validator & Keterangan \\
\hline a. Warna lavar depan (gambar dan huruf) menarik & 5 & Sangat Valid \\
\hline b.Hun fan kalimat iudul menarik perhatian & 5 & Sangat Valid \\
\hline $\begin{array}{l}\text { c. Gambar, ilustrasi, grafik, dan video menarik } \\
\text { perhatian }\end{array}$ & 5 & Sangat Valid \\
\hline d.Tata letal menarilk perhatian & 5 & Sangat Valid \\
\hline e. Animasi pengealan tampilan menarik perhatian & 5 & Sangat Valid \\
\hline f. Tata suara menarik perhatian & 4 & Valid \\
\hline g.Tampilan navigasi menarik & 4 & Valid \\
\hline h.Program mudah digunakan (ramah penggung) & 5 & Sangat Valid \\
\hline Rata-rata & 4,75 & Sangat Valid \\
\hline
\end{tabular}


Tabel 4 Data Tabulasi Angket Oleh Ahli Materi

\begin{tabular}{|c|c|c|}
\hline \multicolumn{3}{|l|}{ Aspek Pokok Bahasan } \\
\hline Kriteria & Validator & Keterangan \\
\hline 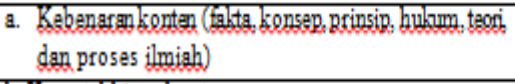 & 4 & Valid \\
\hline b. Kemutahhiran konten & 4 & Valid \\
\hline $\begin{array}{l}\text { c. Keserugian neked bahasan dalam media pembelajaran } \\
\text { dengan Kurikulum } 2013\end{array}$ & 4 & Valid \\
\hline d. Sistematis, sesugi strulktur keilmuan & 4 & Valid \\
\hline Rata-rata & 4 & Valid \\
\hline \multicolumn{3}{|l|}{ Aspek Kebahasaan } \\
\hline Kriteria & Validator & Keterangan \\
\hline $\begin{array}{l}\text { a. Keterbacsan bahasa atau bahasa yang digmaban sesugi } \\
\text { dengan usia peserta didit }\end{array}$ & 4 & Valid \\
\hline b. Mengengakan bahasa yang komunikatif & 4 & Valid \\
\hline c. Istilah yang digunakan tapat dan dapat diphami & 4 & Valid \\
\hline d. Menggunglan istilah dan simbel secara ajeg & 4 & Valid \\
\hline Rata-rata & 4 & Valid \\
\hline \multicolumn{3}{|l|}{ Aspek Penyajian } \\
\hline Kriteria & Validator & Keterangan \\
\hline $\begin{array}{l}\text { a. Membangkitkan motivasi minat rasa ingin the peserta } \\
\text { diditi }\end{array}$ & 4 & Valid \\
\hline $\begin{array}{l}\text { b. Sesugi dengan tarafberfilir dan lemampuan membaca } \\
\text { peserta didik }\end{array}$ & 4 & Valid \\
\hline c. Menderone neserta didil terlibat altif & 4 & Valid \\
\hline 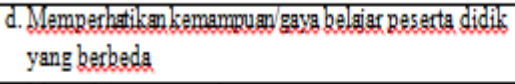 & 4 & Valid \\
\hline e. Mlenarik/menvenangkan & 4 & Valid \\
\hline $\begin{array}{l}\text { f. Memberikan pengalamanlabih nyadg (abstral menjadi } \\
\text { konkrit) }\end{array}$ & 4 & Valid \\
\hline Rata-rata & 4 & Valid \\
\hline
\end{tabular}

$: \frac{\mathrm{vi}+\sqrt{2}}{2}=\frac{4+4}{2}=4$ (valid)

Validasi produk dilakukan untuk memperoleh masukan perbaikan dan selanjutnya memperoleh pengakuan kevalidan produk yang dikembangkan. Penilaian dilakukan dengan menggunakan angket media pembelajaran dengan skala 15 .

Berdasarkan hasil uji kevalidan yang telah dikemukakan, dapat disimpulkan bahwa media laboratorium virtual berbasis multimedia interaktif yang dikembangkan valid dengan rata-rata 4,4 untuk ahli media dan rata-rata 4 untuk ahli materi.

b. Analisis Data Kepraktisan

Data kepraktisan media laboratorium virtual berbasis multimedia interaktif melalui respon guru dan respon peserta didik dan hasil pengamatan pengelolaan pembelajaran.

Tabel 5. Analisis Data Kepraktisan Media Oleh Guru

\begin{tabular}{|c|c|c|c|c|c|}
\hline No & $\begin{array}{l}\text { Appek yang } \\
\text { Dinilai }\end{array}$ & Indikator & Skor & $\begin{array}{l}\text { Persentase } \\
\text { Rata-rata }\end{array}$ & $\begin{array}{l}\text { Kesimpulan } \\
\text { Penilaian }\end{array}$ \\
\hline \multirow[t]{2}{*}{1} & \multirow[t]{2}{*}{ Isi / mgteri } & 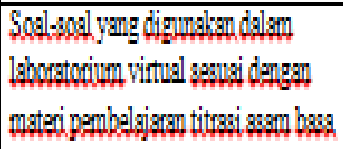 & 4 & \multirow[b]{2}{*}{$90 \%$} & \multirow[b]{2}{*}{ Praltis } \\
\hline & & 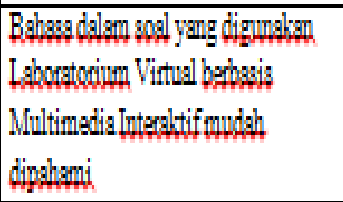 & 5 & & \\
\hline \multirow[t]{5}{*}{2} & \multirow[t]{5}{*}{ Rembelgisam } & 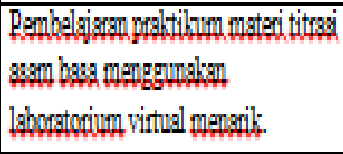 & 4 & \multirow{5}{*}{$84 \%$} & \multirow{5}{*}{ Praltis } \\
\hline & & 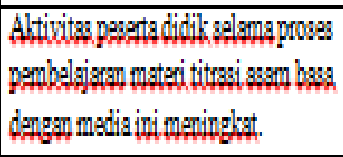 & 5 & & \\
\hline & & 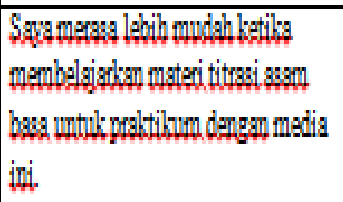 & 4 & & \\
\hline & & 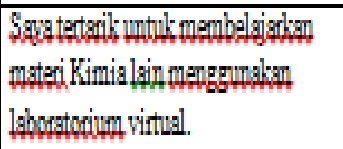 & 4 & & \\
\hline & & 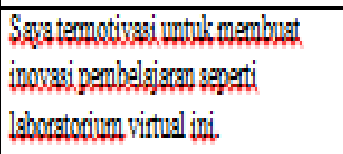 & 4 & & \\
\hline \multirow[t]{5}{*}{3} & \multirow[t]{5}{*}{$\begin{array}{l}\text { Trmpilan } \\
\text { media }\end{array}$} & 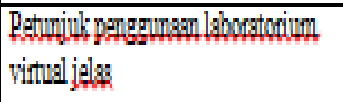 & 5 & \multirow{5}{*}{$96 \%$} & \multirow{5}{*}{ Praktis } \\
\hline & & 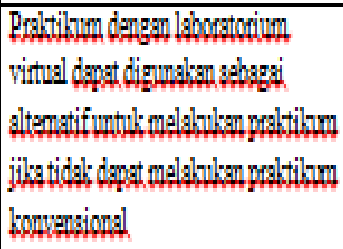 & 5 & & \\
\hline & & $\begin{array}{l}\text { Media yang digunglisan mudeh } \\
\text { dioperasilkan. }\end{array}$ & 5 & & \\
\hline & & 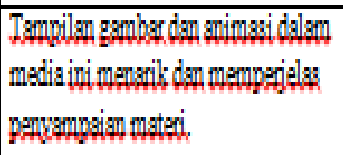 & 5 & & \\
\hline & & 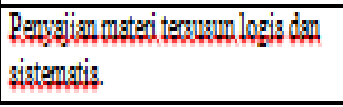 & 4 & & \\
\hline
\end{tabular}


Tabel 6. Analisis Data Kepraktisan Media Oleh Peserta Didik

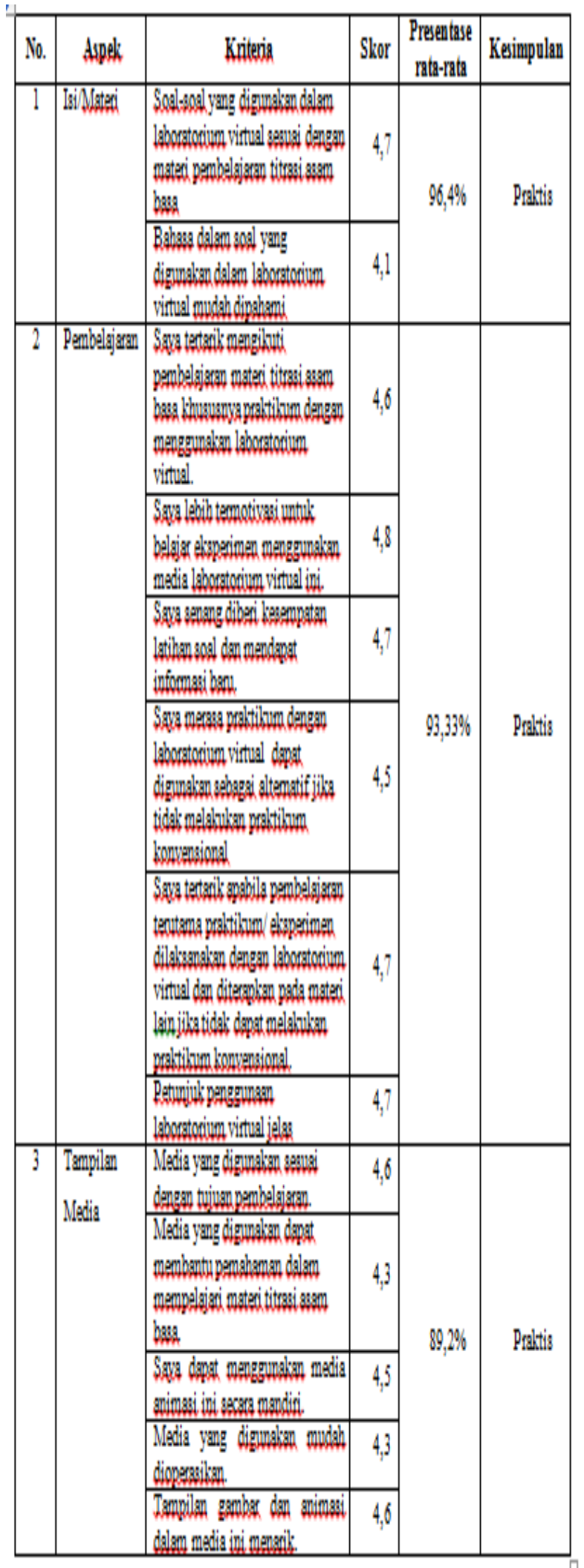

Tabel 7 Data Pengamatan Pengelolaan pembelajaran

\begin{tabular}{|c|c|c|c|c|c|c|c|}
\hline \multirow{3}{*}{ No } & \multirow{3}{*}{ Aspek yang dinilai } & \multicolumn{6}{|c|}{ Hasil Pengamatan } \\
\hline & & \multicolumn{3}{|c|}{ Pl } & \multicolumn{3}{|c|}{ P2 } \\
\hline & & I & II & III & I & II & III \\
\hline 1 & Menyampsilkan deskripsi singkat & 4 & 4 & $\frac{4}{4}$ & 4 & 4 & $\frac{4}{4}$ \\
\hline 2 & Menyampaiksan tujuan & 4 & 4 & 4 & 4 & 4 & 4 \\
\hline 3 & Menyempaikan motivasi & 4 & 4 & 4 & 4 & 4 & 4 \\
\hline 4 & $\begin{array}{l}\text { Menjelsaksm cars menggunakan media } \\
\text { pembelajaran laboratorium virtual berbasis } \\
\text { interaltif }\end{array}$ & 3 & 3 & 3 & 3 & 3 & 3 \\
\hline 5 & Memberi contoh & 3 & 3 & 3 & 3 & 3 & 3 \\
\hline 6 & $\begin{array}{l}\begin{array}{l}\text { Melakulkan demonstrasishow media } \\
\text { pembelgagran }\end{array} \\
\end{array}$ & 3 & 3 & 3 & 3 & 3 & 3 \\
\hline 7 & $\begin{array}{l}\text { Merjelaskan materi/memberi contoh tanpa } \\
\text { menggunakan media pembelajaran } \\
\text { laboratorium virtual berbasis multimedia } \\
\text { interaktif }\end{array}$ & 4 & 3 & 3 & 3 & 4 & 4 \\
\hline 8 & $\begin{array}{l}\text { Memberi media pembelajaran laboratorium } \\
\text { virtual berbasis multimedia interaltif }\end{array}$ & 3 & 4 & 4 & 3 & 4 & 4 \\
\hline 9 & Membimbing/mengarahkan peserta didik. & 3 & 3 & 3 & 3 & 3 & 3 \\
\hline 10 & $\begin{array}{l}\text { Meminta peserta didik untukmenyelessiksn } \\
\text { praktikum }\end{array}$ & 4 & 3 & 3 & 4 & 4 & 4 \\
\hline 11 & $\begin{array}{l}\text { Meminta peserta didik untukmenyelessiksn } \\
\text { latihan }\end{array}$ & 4 & 3 & 3 & 4 & 3 & 3 \\
\hline 12 & $\begin{array}{l}\text { Memberi panjelasan kzpoda paserta didik } \\
\text { tentang materi yang diajarksn }\end{array}$ & 4 & 3 & 3 & 3 & 3 & 4 \\
\hline 13 & $\begin{array}{l}\begin{array}{l}\text { Mengarahksn pesarta didik untuk menarik } \\
\text { kesimpulan }\end{array} \\
\end{array}$ & 4 & 3 & 4 & 4 & 3 & 3 \\
\hline 14 & Memberi tugas untuk dikerjakan di numah & 4 & 4 & 4 & 4 & 4 & 4 \\
\hline 15 & $\begin{array}{l}\text { Menyampaikan materi yang alsan dipelsjari } \\
\text { pada pertemuan beriluunya }\end{array}$ & 4 & 4 & 3 & 4 & 3 & 4 \\
\hline 16 & Peserta didil antusias & 4 & 4 & 4 & 4 & 4 & 4 \\
\hline 17 & Gurn antusias & 3 & 4 & 4 & 4 & 3 & 3 \\
\hline 18 & $\begin{array}{l}\begin{array}{l}\text { Kegiatan gasuai alokasi waktu yang } \\
\text { direncrnalkan }\end{array} \\
\end{array}$ & 3 & 3 & 3 & 3 & 3 & 3 \\
\hline 19 & Kegiatan sesuai alkenario yang ada pada RPP & 3 & 3 & 3 & 3 & 3 & 3 \\
\hline & Jumlah & & & & & & \\
\hline & Rata-rata & & & & & & \\
\hline
\end{tabular}

\section{Keterangan}

$\begin{array}{ll}3,5 \leq \mathrm{KG} \leq 4 & \text { berarti sangat tinggi (ST) } \\ 2,5 \leq \mathrm{KG}<3,5 & \text { berarti tinggi (T) } \\ 1,5 \leq \mathrm{KG}<2,5 & \text { berati culupp tinggi (CT) } \\ \overline{\mathrm{KG}}<1,5 & \text { berarti tidal tinggi (TT) }\end{array}$

Skor maksimume Jumlah pengegmat $\mathrm{x}$ Jumlah ska tiąp pertemuan $\mathrm{x}$ jumlah kegistan $=2 \times 3 \times 4 \times 19=456$

Hasil penilaian guru menurut aspek adalah $90 \%$ dengan kategori praktis, aspek pembelajaran $84 \%$ dengan kategori praktis, aspek tampilan media $96 \%$ dengan kategori praktis. Hasil penilaian peserta didik aspek isi/materi adalah 96,4\% dengan kategori praktis, aspek pembelajaran 93,33\% dengan kategori praktis, aspek tampilan media 89,2\% dengan kategori praktis. 
Berdasarkan hasil pengamatan pengelolaan pembelajaran diperoleh ratarata 3,48 yang artinya tingkat pencapaian pengelolaan pembelajaran $2,5 \leq 3,48<3,5$ berarti tinggi $(\mathrm{T})$ dan dapat dikatakan bahwa guru mampu mengelola pembelajaran.

c. Analisis Data Keefektifan

1) Hasil Pretest-Posttest Peserta didik

Hasil belajar peserta didik diperoleh dengan tes evaluasi pilihan ganda yang diberikan sebelum dan setelah disajikan media laboratorium virtual berbasis multimedia interaktif.

Kategori peningkatan yang digunakan adalah tinggi apabila $g>0,7$; sedang apabila $0,7>g>0,3$; dan rendah apabila $g<0,3$. Berdasarkan hasil yang diperoleh, terdapat peningkatan hasil belajar peserta didik karena gain berada pada 0,785 $>0,73$, sehingga dapat disimpulkan peningkatan hasil belajar berada pada kategori tinggi.

Penentuan ketuntasan kelas dari hasil belajar siswa kelas XI MIA 3 SMA Negeri 6 Takalar diperoleh jumlah siswa yang tuntas sebanyak 20 orang dan jumlah siswa yang tidak tuntas sebanyak 8 orang. Hal ini menunjukkan bahwa siswa yang tuntas lebih banyak daripada siswa yang tidak tuntas terlihat pada persentase pencapaian hasil belajar siswa yaitu $71,42 \%$ yang termasuk dalam kategori tuntas.

2) Aktivitas Peserta Didik

Untuk memperoleh data aktivitas peserta didik, digunakan lembar obeservasi. Pengamatan dilakukan oleh dua orang pengamat. Pengamatan aktivitas peserta didik dilakukan dengan mengamati enam orang peserta didik

Berdasarkan data hasil analisis aktivitas peserta didik pada uji coba, dari 8 kategori yang diamati, ada 6 kategori yang berkaitan dengan pembelajaran terpenuhi (termasuk dalam batas interval yang dapat diterima), yaitu kategori pertama sampai kategori keenam. Sedangkan kategori tujuh dan delapan yaitu kegiatan di luar tugas tidak melewati batas toleransi yang ditentukan. Artinya, kriteria pencapaian waktu ideal aktivitas peserta didik tercapai, yaitu 6 dari 8 kategori terpenuhi dan syarat utama yaitu kategori (1), (2), (3), (4), (5) dan (6) terpenuhi. Hal ini berarti bahwa peserta didik telah melaksanakan proses pembelajaran dengan menggunakan laboratorium virtual berbasis multimedi interaktif.

Dari uraian di atas dapat disimpulkan bahwa media laboratorium virtual berbasis multimedia interaktif memenuhi kriteria keefektifan yaitu aktivitas peserta didik memenuhi batas toleransi yang telah ditentukan.

\section{SIMPULAN DAN SARAN}

1. Proses pengembangan media Laboratorium Virtual Berbasis Multimedia Interaktif sebagai media pembelajaran pada praktikum titrasi asam-basa dilakukan melalui tiga fase yaitu:

a. Analisis kebutuhan (Need Assesment), pada tahap ini diperoleh hasil bahwa untuk materi titrasi asam-basa merupakan salah satu materi yang membutuhkan praktikum. Tetapi, disekolah ini masih minim alat dan bahan praktikum serta tidak adanya waktu guru untuk melakukan praktikum sehingga digantikan dengan laboratorium virtual. Oleh karena itu dibutuhkan media alternatif dalam melakukan praktikum sehingga dapat meningkatkan hasil belajar peserta didik

b. Desain (Design), dihasilkan rancangan media laboratorium virtual berbasis multimedia interaktif dalam bentuk aplikasi flash menggunakan adobe animate $\mathrm{CC}$ yang memuat petunjuk navigasi, peringatan di dalam laboratorium, menu utama yang berisi standar kompetensi dan kompetensi dasar, indikator, ringkasan materi, percobaan titrasi asam basa dan latihan.

c. Pengembangan dan Implementasi (Development and Implementation Phase), merupakan fase kegiatan 
realisasi produk yang terdiri atas : (1) Pembuatan media Laboratorium Virtual Berbasis Multimedia Interaktif; (2) Penilaian dan revisi; (3) produksi media untuk dilakukan uji coba produk; (4) penilaian kelayakan media.

2. Media laboratorium virtual berbasis multimedia interaktif pada praktikum titrasi asam basa yang telah dikembangkan, telah bersifat valid, praktis dan efektif. Oleh karena itu media yang dikembangkan layak dijadikan sebagai media pembelajaran.

\section{DAFTAR RUJUKAN}

Afandi, Muhammad dan Badarudin. 2011. Perencanaan Pembelajaran. Bandung: Alfabeta.

Ariani, N., \& Haryanto, D. (2010). Pembelajaran Multimedia di Sekolah Pedoman Pembelajaran Inspiratif, Konstruktif, dan Prospektif. Jakarta: Prestasi Pustaka.

Arikunto, Suharsimi. 2010. Dasar-Dasar Evaluasi Pendidikan. Jakarta: Bumi Aksara.

Arsyad. 2006. Media Pembelajaran. Jakarta: Raja Grafindo Persada.

Asmawati. 2014. Pengembangan Media Pembelajaran Adobe Flash CS5 pada Materi Pokok Asam Basa. Tesis. Makassar: Pascasarjana UNM.

Babateen, H. M. 2011. The role of virtual laboratories in science education. In 5th International Conference on Distance Learning and Education IPCSIT (Vol. 12, pp. 100-104).

Chun, R. 2017. Adobe Animate CC 2017 release. San Francisco, California: Peachpit, a division of Pearson Education.

Daryanto. 2013. Media Pembelajaran: Peranannya Sangat Penting Dalam Mencapai Tujuan Pembelajaran. Yogyakarta: Gava Media.

Darwis, Muhammad. 2007. Model Pembelajaran Matematika yang Melibatkan Kecerdasan Emosional.
Disertasi tidak diterbitkan. Program Pascasarjana Program Studi Pendidikan Matematika Universitas Negeri Surabaya.

Dianty, Ria Natalia. 2014. Perbandingan Pengaruh antara Pembelajaran Menggunakan Laboratorium Konvensional dan Virtual Laboratorium Terhadap Hasil Belajar Siswa. Makassar: FMIPA UNM.

Dobrzański, L. A., \& Honysz, R. 2011. Virtual examinations of alloying elements influence on alloy structural steels mechanical properties. Journal of Achievements in Materials and Manufacturing Engineering, (Vol. 49, nr 2), 251--258.

Ena, OudaTeda. 2001. Membuat Media Pembelajaran Interaktif dengan Piranti Lunak Presentasi. (online). Yogyakarta: Indonesian Language and Culture Intensive Course Universitas Sanata Dharma. http://www.ialf.edu/kipbipa/papers/ou datedaena.doc. Diakses pada tanggal 12 Agustus 2016.

Galesso, M. 2017. Adobe Animate Cc 2017: An Easy Guide to the Best Features. First Rank Publishing.

Gundogdu, K., Silman, F., \& Ozan, C. (2011). A Comparative Study on Perception of Teachers on the Use of Computers in Elementary Schools of Turkey and T.R.N.C. International Online Journal of Educational Sciences, 3 (1), 113-137

Gunawan, G., Setiawan, A., \& Widyantoro, D. H. 2014. Model Virtual Laboratory Fisika Modern untuk Meningkatkan Keterampilan Generik Sains Calon Guru. Jurnal Pendidikan Dan Pembelajaran (JPP), 20(1), 25-32.

Harahap, N. M. 2011. Pengaruh Penggunaan Laboratorium Virtual dibandingkan dengan Laboratorium Riil dengan Pembelajaran Berbasis Masalah Terhadap Aktivitas dan Hasil Belajar Kimia Siswa SMA Pada 
Pokok Bahasan Laju Reaksi (masters). UNIMED. Retrieved from http://digilib.unimed.ac.id/3212/.

Harjani, T. 2013. Kimia Untuk SMA/MA Kelas X. Solo: Jatra

Hobri. 2009. Metodologi Penelitian Pengembangan (Development

Research) Aplikasi pada Penelitian Pendidikan Matematika. Jember: Universitas Jember.

Jaya, H \& Haryoko, S. 2010. Pengembangan Laboratorium Virtual di SMK Untuk Meningkatkan Kompetensi Siswa Pada Mata Pelajaran Produktif. Jurnal Pendidikan Teknologi dan Kejurusan. Vol. 11.

Jian, Brown DJ \& Billet E. 2005. Development of a virtual laboratory experiment for biology. European Journal of Open, Distance and

E-learning 1 (195):1-8. On Line at http://www.eurodl.org. [diakses tanggal

29 November 2017].

Kean, E., \& Middlecamp, C. 1985. Panduan belajar kimia dasar. Jakarta: PT. Gramedia.

Keller, H. E. Keller. 2005. Making Real Virtual Labs. Science Education Review, 4(1), 2-11.

Mahanta, A., \& Sarma, K. K. 2012. Online resource and ICT-aided virtual laboratory setup. International Journal of Computer Applications, 52(6).

Mardikaningtyas, Dyah Afiat, Ibrohim dan Endang Suarsini. 2016. Pengembangan Pembelajaran Pencemaran Lingkungan Berbasis Penelitian Fitoremediasi untuk Menunjang Keterampilan Ilmiah, Sikap Peduli Lingkungan dan Motivasi Mahasiswa pada Matakuliah Dasar-Dasar Ilmu Lingkungan. Jurnal Pendidikan: Teori, Penelitian dan Pengembangan. Volume 1, Nomor 3 : 499-506.

Martínez, G., Naranjo, F. L., Pérez, Á. L., Suero, M. I., \& Pardo, P. J. 2011.
Comparative study of the effectiveness of three learning environments: Hyper-realistic virtual simulations, traditional schematic simulations and traditional laboratory. Physical Review Special Topics Physics Education Research, 7(2). https://doi.org/10.1103/PhysRevSTPE R.7.020111.

Munir. 2013. Konsep dan Aplikasi Program Pembelajaran Berbasis Komputer (Computer Based Interaction), P3MP, UPI.

Nandi, N. 2016. Penggunaan Multimedia Interaktif dalam Pembelajaran Geografi di Persekolahan. Jurnal Geografi Gea, 6(2).

Nurdin, 2007. Model Pembelajaran Matematika yang Menumbuhkan Metakognitif untuk Menguasai Bahan Ajar. Disertasi. Tidak diterbitkan. Surabaya: PPs Universitas Negeri Surabaya.

Pratomo, Adi. 2015. Pengembangan Media Pembelajaran Interaktif Berbasis Web Menggunakan Metode Hannafin dan Peck. Banjarmasin: Politeknik Negeri Banjarmasin Jurnal Positif, Tahun I, No.1.

Prawiradilaga, D. S. (2007). Mozaik Teknologi Pendidikan. Jakarta: Kencana Prenada Media Group.

Rachmat, Antonius dan Alphone Roswanto. 2005. Chapter 1- Pengantar Multimedia Yogyakarta: Fakultas Teknik Informatika Universitas

Kristen Duta Wacana.

Rohde, M. 2013. Adobe Edge Animate CC for dummies. Hoboken, NJ: John Wiley \& Sons Inc.

Rusyani, Endang. 2012. Desain Pembelajaran.

http://file.upi.edu/Direktori/FIP/JUR. _PEND._LUAR_BIASA/1957051019 85031-

ENDANG_RUSYANI/DESAIN_PE

MBELAJARAN.pdf. Diakses pada tanggal 10 Oktober 2017.

Sadiman, Arief S, dkk. 2008. Media Pendidikan :Pengertian, 
Pengembangan dan Pemanfaatannya. Jakarta : Raja Grafindo Persada.

Sanjaya, Wina. 2012. Perencanaan dan Desain Sistem Pembelajaran. Jakarta :Fajar Interpratama Offset.

Sihalolo, H. 2012. Pengembangan Pembelajaran Berbentuk Video pada Materi Ajar Merakit Amplifier 400 Watt (Doctoral dissertation, UNIMED).

Sugiyono, M. P. P. 2007. Pendekatan Kuantitatif. Kualitatif, Dan R\&D. Bandung: Alfabeta

Suyanto, M. 2005. Analisis \& Desain Aplikasi Multimedia. Penerbit Andi, Yogyakarta.

Tatli, Z., \& Ayas, A. 2010. Virtual laboratory applications in chemistry education. Procedia Social and Behavioral Sciences, 9, 938-942. https://doi.org/10.1016/j.sbspro.2010. 12.263

Tegeh, I. M., Jampel, I. N., \& Pudjawan, K. 2014. Model penelitian pengembangan. Yogyakarta: Graha Ilmu.

Tüysüz, C. 2010. The Effect of the Virtual Laboratory on Students' Achievement and Attitude in Chemistry. International Online Journal of Educational Sciences, 2(1).

Yani, A. 2011. Pengembangan Perangkat Pembelajaran Mata Kuliah Fisika Dasar yang Kontekstual Berbasis Komputer pada Program Studi Pendidikan Fisika, FMIPA Universitas Negeri Makassar. Makassar: Jurusan Fisika UNM.

Yuniarti, F., Dewi, P., \& Susanti, R. 2012. Pengembangan virtual laboratory sebagai media pembelajaran Berbasis komputer pada materi pembiakan virus. Journal of Biology Education, $1(1)$.

Yusuf, Irfan. 2013. Pengembangan Perangkat Pembelajaran Fisika Berbasis Media Laboratorium Virtual Pada Materi Dualisme Gelombang
Partikel Di SMA Tut Wuri Handayani

Makassar. Makassar: Tesis Pasjasarjana UNM 